\title{
Upcycling of food industry side streams by basidiomycetes for production of a vegan protein source
}

\author{
Jenny Ahlborn ${ }^{1} \cdot$ Alexander Stephan $^{2} \cdot$ Theresa Meckel $^{1} \cdot$ Garima Maheshwari ${ }^{1} \cdot$ Martin Rühl $^{1,3} \cdot$ Holger Zorn $^{1,3}$ (])
}

Received: 15 May 2019 / Accepted: 2 December 2019 / Published online: 27 December 2019

(c) The Author(s) 2019

\begin{abstract}
Purpose Novel protein sources are urgently needed to meet the increasing protein demand of a continuously growing world population. This study is focused on the production of protein rich mushroom mycelia on industrial side streams.

Methods Submerged propagation of mushrooms was carried out in shake flasks which contained agro-industrial side streams as the sole carbon source. The biomass obtained was analyzed for its crude protein, ash and fat content as well as for its fatty acid and amino acid profiles. Vitamin $\mathrm{D}_{2}$ production from ergosterol in the biomass was induced by UV-B irradiation and determined by HPLC-DAD. The share of fungal mycelium in the total biomass was determined by extraction and quantitation of ergosterol. Additionally, water and oil binding capacity (WBC and OBC) were evaluated.

Results A screening of basidiomycetes grown on agro-industrial side streams indicated a fast growth of Pleurotus sapidus on apple pomace. After 4 days of cultivation, the biomass obtained from this mushroom-substrate combination contained $21 \%$ true protein in dry matter. In addition to proteins, the amounts of lipids (4\%), ash (2\%) and carbohydrates (74\%) were quantitated. The dominating fatty and amino acids of Pleurotus sapidus grown on apple pomace were linoleic acid and glutamic acid/glutamine, respectively. Concentrations of up to $115 \mu \mathrm{g}$ (g dry matter) $)^{-1}$ vitamin $\mathrm{D}_{2}$ were formed from ergosterol by UV-B irradiation. Ergosterol was used as a biomarker to monitor the amount of fungal content.

Conclusion The nutritional value of agro-industrial side streams such as apple pomace can be upcycled by biotransformation with basidiomycetes.
\end{abstract}

Keywords Apple pomace $\cdot$ Biotransformation $\cdot$ Protein source $\cdot$ Vitamin $\mathrm{D}_{2}$

Electronic supplementary material The online version of this article (https://doi.org/10.1007/s40093-019-00317-4) contains supplementary material, which is available to authorized users.

Holger Zorn

holger.zorn@uni-giessen.de

Jenny Ahlborn

Jenny.Ahlborn@1cb.chemie.uni-giessen.de

Alexander Stephan

stephan@van-hees.com

Theresa Meckel

Theresa.C.Meckel@1c.chemie.uni-giessen.de

Martin Rühl

Martin.Ruehl@uni-giessen.de

1 Institute of Food Chemistry and Food Biotechnology, Justus Liebig University Giessen, Heinrich-Buff-Ring 17, 35392 Giessen, Germany

2 VAN HEES GmbH, Kurt-van-Hees-Str. 1, 65396 Walluf, Germany

3 Fraunhofer Institute for Molecular Biology and Applied Ecology, Winchester Str. 2, 35394 Giessen, Germany

\section{Introduction}

Fungi have been considered as a desirable source of human nourishment for thousands of years. Because of their high nutritional value and pleasant taste, the fruiting bodies of mushrooms are commonly consumed. They are rich in fiber (i.e., chitin and glucan), contain all essential amino acids, vitamin $\mathrm{D}_{2}$, several vitamins of the $\mathrm{B}$ group, and have low fat contents (Manzi et al. 1999). Due to their low energy content, they represent an ideal food for low calorie diets. Fruiting bodies of the oyster mushroom Pleurotus ostreatus have been reported to lower the oxidized low density lipoprotein (oxLDL) and triacylglycerol levels in the blood and help maintain a normal blood cholesterol level (Alam et al. 2009; Schneider et al. 2011). In addition to the fruiting bodies, vegetative mycelia of fungi are consumed as food as well. Prominent examples include tempeh, which is produced by fermentation of soy beans with the mucoromycete Rhizopus oligosporus, and Quorn ${ }^{\mathrm{TM}}$ which is based on the 
mycelium of the mold Fusarium venenatum. These mycelia based foods are consumed as alternatives to meat. Currently, there is an increasing demand for meat-analogue products. Microbial proteins offer the advantages of additional health benefits, minimization of animal slaughter and a reduction in the carbon foot print of food production. In addition, mycoprotein is deemed as a high quality protein with a Protein Digestibility-Corrected Amino Acid Score (PDCAAS) of 0.91 (Miller and Dwyer 2001), which is comparable to that of animal proteins such as casein, egg white and beef with PDCAAS values of 1.0, 1.0 and 0.92 , respectively (Singh et al. 2008). Fungal mycelia are also considered to provide a high protein to energy ratio. For example, a fillet of beef provides $0.18 \mathrm{~g}$ protein per kcal, while $P$. ostreatus delivers $0.21 \mathrm{~g}$ protein per kcal (based on data from Andersen and Soyka 2011).

Apart from valuable proteins, fungi contain ergosterol, the direct precursor of vitamin $\mathrm{D}_{2}$, which is a structural analogue of vitamin $\mathrm{D}_{3}$. Vitamin $\mathrm{D}_{3}$ is formed in the skin from 7-dehydrocholesterol after exposure to sunlight or can be supplied by a few animal sources, such as egg yolk or fish. Vegetarian or vegan diets may cause a vitamin D deficiency, which can lead to severe osteoamalacia and rickets due to insufficient bone mineralization. Ergosterol, located in the cell membrane of fungi, is easily transformed to vitamin $\mathrm{D}_{2}$ by UV-B exposure (Roberts et al. 2008).

Apples belong to the most popular fruits worldwide, and the world production of fresh apples amounted to 89 million tons in 2016 (FAO 2018). Frequently, apples are pressed for production of juice, and apple pomace, consisting of peels, seeds and pulp, accrues as side stream. Currently, apple pomace is either used as feed for ruminants or it is incinerated. Recently, Aghili et al. (2019) analyzed the effects of apple pomace as poultry feed. They found adverse effects regarding growth performance and some blood parameters. In Germany, 200-250 thousand tons of fresh apple pomace are produced every year (Kammerer et al. 2014). This agroindustrial side stream is available throughout the year, thus making it an ideal carbohydrate source for mushroom production. Villas-Bôas et al. (2003) valorized apple pomace using it as a substrate for solid-state fermentation of Candida utilis and Pleurotus ostreatus. The product obtained from this fermentation was fed to ruminants in their study. Another important side stream is molasses. It accrues as one of the major by-products of the sugar industry and is either fed to animals or used as a substrate for yeast production. However, only approximately $60 \%$ of the molasses arising in Germany, which amounts to 650 thousand tons, is used. Molasses are rich in carbohydrates and may be used as substrate for mushroom production.

In this study, basidiomycetes (edible mushrooms) were grown in submerged cultures which contained industrial side streams as sole carbon source. This resulted in the conversion of apple pomace into nutritionally valuable mushroom mycelia. Finally, the mycelia were enriched in vitamin $\mathrm{D}_{2}$.

\section{Materials and methods}

\section{Cultivation of microorganisms}

Agrocybe aegerita, strain 4022 (AAE) was received from Sylvan (NT Horst, The Netherlands), Pleurotus sapidus, strain 8266 (PSA) from DSMZ (Braunschweig, Germany), Lentinula edodes, strain 389.89 (LED), Wolfiporia cocos, strain 279.55 (WCO) from the Dutch Westerdijk Fungal Biodiversity Institute (Utrecht, The Netherlands) and Stropharia rugosoannulata, strain M 5012 (SRU) from Mycelia (Nevele, Belgium). Pleurotus sajor-caju (PSC) and Pleurotus salmoneostramineus were obtained from the institute's culture collection and were cultivated on apple pomace only. These fungi were selected based on data from previous studies (Bosse et al. 2013; Stephan et al. 2018). All cultivation procedures were performed under sterile conditions. Stock cultures were maintained on malt extract agar plates $\left(20 \mathrm{~g} \mathrm{~L}^{-1}\right.$ malt extract, $15 \mathrm{~g} \mathrm{~L}^{-1}$ agar agar) at $24{ }^{\circ} \mathrm{C}$ in darkness.

Pre-cultures were prepared as described by Trapp et al. (2018), and were grown for 6-13 days: AAE 11 d, LED $13 \mathrm{~d}$, LSU 13 d, PSA 6 d, SRU 7 d and WCO 7 d. For the main cultures, the carbohydrate content of each side-stream was calculated (see 2.5) and adjusted to $15 \mathrm{~g}$ carbohydrate per liter medium as the sole carbon source. In the case of apple pomace $23.7 \mathrm{~g} \mathrm{DM}$ were used per liter. According to Bosse et al. (2013) a medium containing L-aspartic acid, $\mathrm{NH}_{4} \mathrm{NO}_{3}$, $\mathrm{KH}_{2} \mathrm{PO}_{4}, \mathrm{MgSO}_{4} \cdot \mathrm{H}_{2} \mathrm{O}$ and $1 \mathrm{~mL}$ trace element solution was used. The composition of the trace element solution was adapted from Trapp et al. (2018). Prior to sterilization, the $\mathrm{pH}$ was adjusted to 6.0 with $1 \mathrm{~mol} \mathrm{~L}^{-1} \mathrm{NaOH}$. The respective amount of substrate and $200 \mathrm{~mL}$ medium were transferred to a $500 \mathrm{~mL}$ Erlenmeyer flask and inoculated with $20 \mathrm{~mL}$ of the homogenized pre-culture (Ultra Turrax $30 \mathrm{~s}, 10,000 \mathrm{rpm}$ ). Cultivation was performed at $24{ }^{\circ} \mathrm{C}$ and $150 \mathrm{rpm}$ in the dark. The fully grown cultures were harvested by centrifugation $\left(10 \mathrm{~min}, 4^{\circ} \mathrm{C}, 3300 \mathrm{~g}\right)$, and the mycelium was washed three times with water and freeze-dried for further analysis.

\section{Substrates}

As substrates for the submerged cultivation, different pomaces (apple, pomegranate and aronia), leaf spinach and beet molasses were investigated. They were obtained from industrial partners. Leaf spinach was stored at $-20{ }^{\circ} \mathrm{C}$ and molasses at $4{ }^{\circ} \mathrm{C}$. The other substrates were stored at room temperature in the dark. The substrates were used untreated 
except for leaf spinach, which was lyophilized and ground to powder with a particle size of $\leq 2 \mathrm{~mm}$.

\section{Selection criteria}

Culture period, obtained dry matter, and protein content of the biomass were chosen as selection criteria.

\section{Chemicals}

Standards for vitamin D and ergosterol analyses were purchased from Sigma-Aldrich (Steinheim, Germany): cholecalciferol (vitamin $D_{3}$ ) $99.9 \%$, ergocalciferol (vitamin $D_{2}$ ) $99.1 \%$, ergosterol and 7-dehydrocholesterol $\geq 95.0 \%$. The amino acid calibration standard was purchased from Sykam (Fuerstenfeldbruck, Germany), and L-tryptophan $\geq 99.0 \%$ from Roth (Karlsruhe, Germany). All chemicals were at least of analytical grade and solvents for chromatography of HPLC-grade.

\section{Analysis of substrates and fungal lyophilisates}

Moisture content was determined by a Moisture Analyzer MA35 (Sartorius, Göttingen, Germany). Total nitrogen was analyzed based on the method of Kjeldahl (1883) and Matissek et al. (2010). The amount of ash was determined by difference in weight after total incineration at $550{ }^{\circ} \mathrm{C}$. The fat content was determined after acid treatment and extraction with petroleum ether (Soxtherm rapid extraction system, Gerhardt, Koenigswinter, Germany). The amount of carbohydrates was calculated as difference to $100 \%$.

\section{Fatty acid profile}

The fatty acid profile was analyzed by gas chromatography (Agilent Technologies 7890 A, Varian Optima FFAP $30 \mathrm{~m} \times$ $0.25 \mathrm{~mm}$ ID, $0.25 \mu \mathrm{m}$ film thickness) after transesterification with boron triflouride.

\section{Glucan analysis}

The Mushroom and Yeast Beta-Glucan, (Megazyme Inc., Ireland) enzyme assay kit was used for glucan analysis. Total glucans and $\alpha$-glucans were determined according to the manufacturer's protocol, and the amount of $\beta$-glucans was calculated as the difference.

\section{Chitin analysis}

Chitin was quantitated based on a method of Smith and Gilkerson (1979) which employed a colourimetric assay of 3-methyl-2-benzothiazolinone hydrazone hydrochloride $(\mathrm{MBTH})$ at $650 \mathrm{~nm}$, with slight modifications. Briefly,
$20 \mathrm{mg}$ sample was hydrolyzed with $2.5 \mathrm{~mL} 6 \mathrm{M} \mathrm{HCl}$ at $105^{\circ} \mathrm{C}$. After $24 \mathrm{~h}$, the $\mathrm{pH}$ was adjusted to 7.0 using $\mathrm{NaOH}$ $(6 \mathrm{M}, 1 \mathrm{M}$ and $0.1 \mathrm{M})$. The volume was made up to $10 \mathrm{~mL}$ using ultra-pure water. $100 \mu \mathrm{L}$ of the filtered solution was diluted $1: 10$ by adding $500 \mu \mathrm{L} 0.5 \mathrm{M} \mathrm{HCl}$ and $400 \mu \mathrm{L}$ water. This mixture was incubated for another $2 \mathrm{~h}$ at $105{ }^{\circ} \mathrm{C}$. Next, $2 \mathrm{~mL}$ sodium nitrite $(2.5 \%)$ was added and incubated for 15 min following which $1 \mathrm{~mL}$ ammonium sulphamate $(12.5 \%)$ was added to the samples. After another $5 \mathrm{~min}, 1 \mathrm{~mL}$ MBTH solution $(0.25 \%)$ was added, mixed and incubated for $30 \mathrm{~min}$ at $37^{\circ} \mathrm{C}$. Finally, $1 \mathrm{~mL} \mathrm{FeCl}{ }_{3} \bullet 6 \mathrm{H}_{2} \mathrm{O}$ $(0.5 \%)$ was added and the sample was incubated for $5 \mathrm{~min}$ at $37{ }^{\circ} \mathrm{C}$. Standards containing $N$-acetyl-D-glucosamine $\left(6.18-61.8 \mu \mathrm{g} \mathrm{mL}^{-1}\right)$ were analyzed in the same way as the samples. This resulted in a calibration curve with a regression equation, $y=0.0172 \mathrm{x}+0.0119$, and a $R^{2}=0.9981$.

\section{Amino acid analysis}

For identification and quantitation of amino acids in the lyophilized biomass after total hydrolysis, an amino acid analyzer S433 with columns LCA K13/Na and LCA K04/ $\mathrm{Na}$ (Sykam) and Chromstar software (version 7) was used. According to the manufacturer's protocol, a gradient of two sodium citrate buffer solutions (A: $0.17 \mathrm{M}, \mathrm{pH} 3.4$; B: $0.20 \mathrm{M}, \mathrm{pH} 10.85$; Sykam) and a regenerating solution (RegSol Na 0.5 M, Sykam) were used. Ninhydrin (0.2 M, $\mathrm{pH} 10.85$, Sykam) was used for derivatization. The amino acids were separated at a flow rate of $0.45 \mathrm{~mL} \mathrm{~min}{ }^{-1}$ and quantified by single-point calibration $(n=3)$; the injection volume was $50 \mu \mathrm{L}$.

Acid hydrolysis for total amino acids and oxidative acid hydrolysis for cysteine and methionine were performed, as described in Commission Directive 98/64/EC of the European Unions. Tryptophan analysis was carried out analogous to the acid hydrolysis with slight modifications. Approximately $250 \mathrm{mg}$ sample was mixed with $25 \mathrm{~mL} \mathrm{NaOH} \mathrm{(5} \mathrm{M}$ with $0.1 \%$ phenol) instead of $\mathrm{HCl}$ and heated at $110{ }^{\circ} \mathrm{C}$ for $24 \mathrm{~h}$. After hydrolysis, the $\mathrm{pH}$ was adjusted to 2.2 with $10 \mathrm{~mL} 0.5 \mathrm{M}$ phosphoric acid, followed by $3.75 \mathrm{M}$ and $1 \mathrm{M}$ $\mathrm{HCl}$.

The biological value (BV) was calculated using the amino acid score (AAS), the chemical score (CS) and the essential amino acid index (EAAI). Equations are shown in the supplementary material.

\section{Calculation of the Kjeldahl factor}

Summing up all of the analyzed single amino acids (AA) would cause overestimation of the protein content. Thus, it was necessary to calculate amino acid residues $\left(\mathrm{AA}_{\mathrm{res}}\right)$ which took into account the loss of water that takes place during the formation of peptide bonds. Nitrogen-to-protein 
conversion factors $(N)$ found in literature mostly do not consider this. To calculate the true protein content, $N_{\text {net }}$ was calculated as $\mathrm{AA}_{\text {res }}$ divided by the total nitrogen content, which was analyzed by Kjeldahl's method.

\section{Quantitation of vitamin $D_{2}$ by HPLC-DAD}

Two gram lyophilized biomass of Pleurotus sapidus grown on apple pomace was spread onto a crystallizing dish with a diameter of $19.5 \mathrm{~cm}$ and exposed to UV-B light at room temperature. Three UV-B Medical Hg lamps, Arimed B12 $9 \mathrm{~W}$ (compact) from Philips (Amsterdam, NL) with an emission maximum of 290-310 nm were used as UV source. Lamps were mounted at a distance of $13 \mathrm{~cm}$ from each other and $10 \mathrm{~cm}$ to the working surface. Irradiance was measured by Newport Power Meter model 1918R with sensor 818P015-19 and amounted to $4.44 \mathrm{~mW} \mathrm{~cm}^{-2}$. After irradiation for up to $45 \mathrm{~min}$, the lyophilised biomass was ground to a fine powder in liquid nitrogen, and the liquid-liquid extraction of vitamin $\mathrm{D}$ was performed as described by Ahlborn et al. (2018). Vitamin $D_{3}$ was used as the internal standard. HPLC-DAD was used for detection of vitamin $\mathrm{D}_{2}$ at a wavelength of $265 \mathrm{~nm}$ (Ahlborn et al. 2018).

\section{Quantitation of fungal mycelium using ergosterol as biomarker}

$0.15-0.2 \mathrm{~g}$ of lyophilised biomass was extracted with the method described for vitamin $\mathrm{D}$, using 7-dehydrocholesterol (7-DHC, $0.5 \mathrm{~mL}$ of $1 \mathrm{mg} \mathrm{mL}^{-1}$ in methanol) as the internal standard. Quantitation was performed by HPLC-DAD at a detection wavelength of $282 \mathrm{~nm}$. Limits of detection (LOD) and of quantitation (LOQ) were calculated based on DIN 32645 resulting in a LOD of $7.06 \mu \mathrm{g} \mathrm{mL} \mathrm{m}^{-1}$ and a LOQ of $25.10 \mu \mathrm{g} \mathrm{mL}^{-1}$, corresponding to 53.2 and $188.3 \mu \mathrm{g}(\mathrm{g} \mathrm{DM})^{-1}$, respectively.

For determining the ergosterol amount of pure fungal biomass, the basidiomycete was cultivated in malt extract medium $\left(20 \mathrm{~g} \mathrm{~L}^{-1}\right)$, and the mycelium was harvested and lyophilized as described above. As this medium did not contain insoluble components, the lyophilisate was assumed to contain $100 \%$ fungal biomass.

\section{Functional characteristics}

The functional properties of the mycelium of $P$. sapidus grown on apple pomace were analyzed by measuring the water and oil binding capacity (WBC and OBC) as well as the influence of various salts (food additives) on the water binding capacity. WBC and OBC were determined according to Stephan (2018). The determination was carried out in five replications. The fungal biomass was compared to other commercially available plant proteins, soy protein isolate
(Gushen, China, $90.2 \%$ protein content), soy protein concentrate (Gushen, China, $69.8 \%$ protein content) and pea protein isolate (Cosucra, Belgium, 90.1\% protein content), which were used in meat analogues. To evaluate the influence of various salts on the WBC, $15 \mathrm{~g} \mathrm{~kg}^{-1}$ sodium chloride (esco, Germany), potassium chloride (Jaeklechemie GmbH\&Co. KG, Germany), magnesium chloride (Sapho GmbH, Germany) or calcium chloride (Chemische Fabrik Kalk, Germany) were added.

\section{Statistical analysis}

Average values and standard deviations were calculated for WBC and OBC, and one-way Analysis of Variance (ANOVA) with pairwise PostHoc Test (Tukey Test) was conducted. A significance level of $p<0.05$ was selected. The Grubbs outlier test with a significance level of $p<0.05$ was also performed. For other values half range was calculated in case of duplicates and in case of multiples standard deviation was calculated.

\section{Results and discussion}

\section{Screening of basidiomycete-substrate combinations}

No satisfying growth was achieved with pomegranate and aronia pomace as well as with leaf spinach and beet molasses as carbon sources (Supplementary Fig. 1). All seven basidiomycetes grew well on apple pomace (Table 1). Pleurotus sajor-caju showed the highest biomass but only $14.6 \%$ protein. Pleurotus sapidus showed the second highest formation

Table 1 Performance of several basidiomycetes on apple pomace with corresponding mycelial biomass, protein content and cultivation periods

\begin{tabular}{llll}
\hline Mushroom & DM $\left(\mathrm{g} \mathrm{L}^{-1}\right)$ & $\begin{array}{l}\text { Crude protein }(\% \\
\mathrm{DM})\end{array}$ & $\begin{array}{l}\text { Main } \\
\text { culture } \\
(\mathrm{d})\end{array}$ \\
\hline AAE & $13.3 \pm 0.1$ & $18.6 \pm 0.2$ & 6 \\
LED & $9.6 \pm 0.1$ & $20.4 \pm 0.2$ & 6 \\
PSA & $14.5 \pm 0.2$ & $25.4 \pm 0.3$ & 4 \\
PSC & $15.3^{\mathrm{a}}$ & $14.6^{\mathrm{a}}$ & 3 \\
PSS & $11.7 \pm 0.1$ & $20.9 \pm 0.3$ & 3 \\
SRU & $13.6 \pm 0.5$ & $12.3 \pm 0.3$ & 13 \\
WCO & $13.2 \pm 0.9$ & $9.6 \pm 0.1$ & 26 \\
\hline
\end{tabular}

AAE Agrocybe aegerita, LED Lentinula edodes, PSA Pleurotus sapidus, PSC Pleurotus sajor-caju, PSS Pleurotus salmoneostramineus, SRU Stropharia rugosoannulata, WCO Wolfiporia cocos

$D M$ dry matter, $d$ days

${ }^{\text {a }}$ Single analysis 
of biomass on apple pomace but the highest protein content (25.4\%). Therefore, this combination was chosen for further analysis. The ability of mushrooms to grow on different substrates depends on the presence of nutrients in these substrates. Apple pomace is a versatile substrate for biotechnological applications, such as enzyme, chitosan, and aroma production as well as nutritional enrichment (Vendruscolo et al. 2008). Villas-Bôas et al. (2003) studied the solid-state fermentation of apple pomace by Candida utilis and Pleurotus ostreatus to increase the digestibility for use as ruminant feed. They found that $P$. ostreatus and $C$. utilis increased the crude protein contents. Worrall and Yang (1992) produced shiitake and oyster mushrooms on a mixture of apple pomace and sawdust. Both mushrooms grew faster and more densely when apple pomace was added. They suggested that the nitrogen level provided by the apple pomace contributed to a better growth. To calculate the protein content, different nitrogen-to-protein-conversion factors are needed due to the differences in chitin contents of the mushroom species (Crisan and Sands 1978). To compare the protein content within the study, the nitrogen content of all Pleurotus species was multiplied by a factor of 4.97 according to Mattila et al. (2002). For Lentinula edodes a factor of 4.50 (Mattila et al. 2002) was applied, and for the remaining mushrooms a factor of 4.38 was used (Crisan and Sands 1978). With Pleurotus sapidus grown on apple pomace, a crude protein content of $25.4 \%$ was obtained. Guo et al. (2007) reported $20.4 \%(N=4.38)$ protein for fruiting bodies of $P$. sapidus, which is in good accordance with the results for mycelia in this study.

\section{Analysis of the substrate}

Apple pomace was analyzed for its chemical composition: true protein $\mathrm{AA}_{\text {res }}(4.3 \pm 0.0) \%\left(N_{\text {net }}=4.15\right.$, analyzed by amino acid analysis), ash (1.5 \pm 0.0$) \%$ and fat $(3.0 \pm 0.3) \%$. The total carbohydrate contents of $(91.2 \pm 0.1) \%$ were calculated. The fatty acid profile was dominated by linoleic acid (51\%), followed by oleic acid (30\%) and palmitic acid (12\%). These results are comparable to those of Ravn-Haren et al. (2018), who determined 4.6\% fat and Givens and Barber (1987), who determined $6.7 \%$ proteins and $2.3 \%$ ash. The composition may vary due to stage of ripeness and the variety of apples. The amino acids (AA) analyzed by total hydrolysis (Supplementary Fig. 1) summed up to $(4.98 \pm 0.06) \mathrm{g}(100 \mathrm{~g} \mathrm{DM})^{-1}$, with tryptophan as the first limiting amino acid.

\section{Composition of Pleurotus sapidus mycelium grown on apple pomace}

The analysis of lyophilised mycelia of $P$. sapidus revealed $\sim 4 \%$ lipids (45\% linoleic acid, $29 \%$ oleic acid, $16 \%$ palmitic acid), $2 \%$ ash and a true protein content $\left(\mathrm{AA}_{\mathrm{res}}\right)$ of $21 \%$. Dimou et al. (2002) reported a mycelial fatty acid profile for $P$. sapidus grown on potato dextrose broth as follows: $14.9 \% \mathrm{C} 16: 0,9.6 \% \mathrm{C} 18: 0,21.4 \% \mathrm{C} 18: 1$ and $52.6 \%$ C18:2. Comparable profiles have been reported for other Pleurotus species (Hadar and Cohen-Azari 1986; Kavishree et al. 2008; Yilmaz et al. 2006). For a healthy diet, an intake of polyunsaturated fatty acids is essential. With $45 \%$ linoleic acid $P$. sapidus can contribute to a healthy and balanced diet.

The calculated carbohydrate content was $74 \%$. Guo et al. (2007) reported a crude protein content of $20 \%$, and $5 \%$ of both ash and fat for fruiting bodies of $P$. sapidus. For other Pleurotus species, crude protein contents of $10-25 \%, 2-4 \%$ fat and 6-8\% ash have been reported (Alam et al. 2008; Crisan and Sands 1978). These values are similar to the data determined for submerged cultivated mycelia of $P$. sapidus in this study.

The amounts of total glucans, $\beta$ - and $\alpha$-glucans of $P$. sapidus cultivated on apple pomace were $(9.2 \pm 0.2) \%$, $(5.6 \pm 0.2) \%$ and $(3.6 \pm 0.1) \%$, respectively. In apple pomace $(4.4 \pm 1.0) \%$ total glucans, $(3.6 \pm 1.0) \% \beta$-glucans and $(0.8 \pm 0.0) \% \alpha$-glucans were analyzed. As expected, chitin was not detected in apple pomace, whereas $(6.3 \pm 0.4) \%$ chitin was determined for mycelia of PSA grown on apple pomace. The dietary fibers reported here may show beneficial health effects, such as reduction of blood cholesterol and stimulation of the immune system (Manzi and Pizzoferrato 2000). $\beta$-Glucans from Pleurotus spp. are called "pleuran" and are considered to be the most biologically effective glucans, especially with respect to their anticarcinogenic properties (Rop et al. 2009).

\section{Amino acid profile}

Based on the sum of amino acids determined after protein hydrolysis, a protein content of $(24.01 \pm 0.35) \mathrm{g}(100 \mathrm{~g}$ $\mathrm{DM})^{-1}$ was calculated for $P$. sapidus grown on apple pomace after 4 days (Table 2). $\mathrm{AA}_{\text {res }}$ resulted in $(20.70 \pm 0.31) \%$ for PSA ATD and $(4.27 \pm 0.05)$ for ATD resulting in Kjeldahl factors $N_{\text {net }}$ of 4.11 (PSA ATD) and 4.15 (ATD), respectively.

The amino acid profile was in good agreement with those of other Pleurotus spp. reported in the literature (Manzi et al. 1999; Table 2). Compared to the mycoprotein derived from Fusarium venenatum (Rodger 2001; Table 2) a significantly higher percentage of histidine was determined for P. sapidus, while that of tryptophan was lower. Methionine and cysteine represented the limiting amino acids in the lyophilised mycelia of $P$. sapidus. The total protein content of $F$. venenatum (48\% in DM; Rodger 2001) was higher compared to the protein content of $P$. sapidus (25.4\%).

The comparison of the sum of amino acids (AA) of apple pomace and of $P$. sapidus grown on apple pomace showed a 
Table 2 Amino acid profile of $P$. sapidus grown on apple pomace in contrast to literature data

\begin{tabular}{|c|c|c|c|c|}
\hline \multirow{3}{*}{ Amino acid } & \multicolumn{4}{|c|}{ Amino acid amount } \\
\hline & \multicolumn{2}{|l|}{ This study } & \multicolumn{2}{|c|}{ Literature (\% of total amino acids) } \\
\hline & $\mathrm{g}(100 \mathrm{~g} \mathrm{DM})^{-1}$ & $\begin{array}{l}\text { (\% of total } \\
\text { amino acids) }\end{array}$ & Mycoprotein & 12 Pleurotus spp. \\
\hline Alanine & 1.39 & 5.78 & 6.30 & $5.97-9.46$ \\
\hline Arginine & 2.32 & 9.67 & 7.30 & $3.72-11.66$ \\
\hline Aspartic acid/asparagine & 2.07 & 8.64 & 10.30 & $9.14-12.09$ \\
\hline Cysteine & 0.27 & 1.10 & 0.80 & $1.23-1.84$ \\
\hline Glutamic acid/glutamine & 4.35 & 18.09 & 12.50 & $12.76-18.68$ \\
\hline Glycine & 1.08 & 4.51 & 4.30 & $4.38-6.25$ \\
\hline Histidine & 2.45 & 10.19 & 3.50 & $3.16-4.26$ \\
\hline Isoleucine & 0.91 & 3.78 & 5.20 & $3.50-4.70$ \\
\hline Leucine & 1.63 & 6.81 & 8.60 & $3.42-7.28$ \\
\hline Lysine & 1.11 & 4.62 & 8.30 & $3.08-6.87$ \\
\hline Methionine & 0.36 & 1.48 & 2.10 & $0.99-2.34$ \\
\hline Phenylalanine & 0.99 & 4.13 & 4.90 & $2.84-4.69$ \\
\hline Proline & 1.03 & 4.29 & 4.50 & $3.49-4.69$ \\
\hline Serine & 1.16 & 4.81 & 5.10 & $3.49-8.43$ \\
\hline Threonine & 0.97 & 4.04 & 5.50 & $4.65-6.95$ \\
\hline Tryptophan & 0.19 & 0.80 & 1.60 & $1.10-1.48$ \\
\hline Tyrosine & 0.64 & 2.66 & 4.00 & $2.76-4.63$ \\
\hline Valine & 1.10 & 4.60 & 6.20 & $3.79-5.74$ \\
\hline
\end{tabular}

Source: Rodger (2001); Manzi et al. (1999)

$D M$ dry matter significant enrichment of proteins. Apple pomace contained only about $5 \%$ amino acids, whereas the fermented pomace resulted in $24 \%$. Fermentation of apple pomace by basidiomycetes thus delivers a vegan food rich in proteins. The biological value (86) of the fermented pomace is high and indicates a good nutritional value for humans.

\section{Vitamin D}

By irradiation of $P$. sapidus grown on apple pomace with UV-B light, an enrichment of vitamin $\mathrm{D}_{2}$ up to $115 \mu \mathrm{g}$ (g $\mathrm{DM})^{-1}$ was achieved. A maximum was observed after 20 min of irradiation (Fig. 1), which has already been found in previous studies (Ahlborn et al. 2018; Wittig et al. 2013). The vitamin $\mathrm{D}$ content of the final product may be adjusted by mixing with non-illuminated lyophilisate. For adults, the daily reference intake of vitamin D is $5 \mu \mathrm{g}$ (Regulation (EU) No 1169/2011). In 2015, the Deutsche Gesellschaft für Ernaehrung (DGE) recommended a daily intake of $10 \mu \mathrm{g}$ for infants (0-1 year) and of $20 \mu \mathrm{g}$ for children and adults.

\section{Quantitation of fungal biomass in lyophilisate}

Using biomass dry weight as a parameter to monitor cell growth is inappropriate for cultures containing insoluble substrates and microbial biomass. In both solid-state and

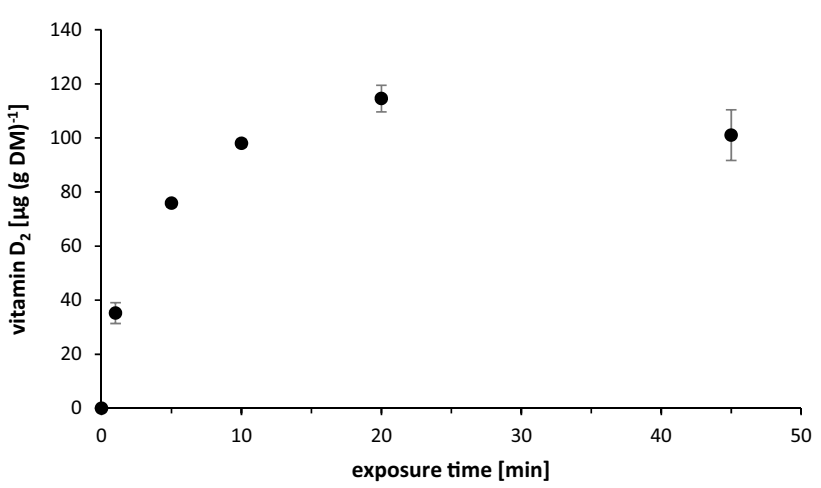

Fig. 1 Enrichment of vitamin $\mathrm{D}_{2}$ in PSA ATD by UV-B irradiation (irradiance $4.44 \mathrm{~mW} \mathrm{~cm}^{-2}$ ). Vertical lines refer to the value of the standard error (SE)

submerged fermentation using solids as substrates, a fermentation process might not lead to complete degradation of the substrate. Therefore, an appropriate biomarker is needed. Fungi contain the mycosterol ergosterol, located almost exclusively in the fungal cell membrane. Ergosterol has been widely used as a biomarker and indicator for fungal growth, e.g., in soil, compost, ectomycorrhizal communities and in other applications since the late 1970s (Kim et al. 2005; Klamer and Bååth 2004; Martin et al. 1990; Porep et al. 2014; Seitz et al. 1977, 1979; Zelles et al. 1987). 
The growth of $P$. sapidus on apple pomace (Fig. 2) was monitored by measuring the ergosterol content over a period of 6 days. The fungal dry matter was calculated using mycelium cultivated on malt extract medium, a completely soluble substrate, as reference. The biomass obtained from this culture was assumed to contain $100 \%$ fungal mycelium. $P$. sapidus grown on malt extract medium contained $(7148 \pm 354) \mu \mathrm{g}(\mathrm{g} \mathrm{DM})^{-1}$ ergosterol $(n=6)$.

The experiments described above were carried out with $P$. sapidus mycelium grown on apple pomace harvested on the 4 th culture day. At this point of time, the share of the fungal mycelium in the total biomass was about $51 \%$. An extended cultivation period did not lead to significantly different amounts. Therefore, various attempts were made to increase the share of fungal mycelium in the lyophilisate. Reducing the amount of apple pomace in the culture medium by $50 \%$ and $75 \%$ resulted in $55 \%$ and $90 \%$ mycelium, respectively. However, this came along with decreased amounts of $7.3 \mathrm{~g} \mathrm{~L}^{-1}$ and $3.2 \mathrm{~g} \mathrm{~L}^{-1}$ lyophilisate, respectively. Finally, a fed-batch fermentation led to $89 \%$ mycelium in $5.4 \mathrm{~g} \mathrm{~L}^{-1} \mathrm{DM}$. To achieve this, the starting concentration of apple pomace was $5.92 \mathrm{~g} \mathrm{DM} \mathrm{L}^{-1}$, which was added again after 4 days and the fermentation was continued for another 2 days. The share of the protein content in the mycelium decreases slightly with increasing cultivation time. At the 2nd day of cultivation the protein share was $44 \%$ after subtracting the blank value, followed by $38 \%, 33 \%, 35 \%$ and $32 \%$ from 3rd to 6th day of cultivation. A decrease in protein content was also observed by Steuder and Bley (2015) and Ooijkaas et al. (1998).

\section{Functional characteristics}

\section{Water and oil binding capacities}

According to Stephan (2018) the average value of WBC was $(6.7 \pm 0.1) \mathrm{mL} \mathrm{g}^{-1}$ for $P$. sapidus grown on apple pomace, which was significantly higher than those of the reference proteins pea protein isolate $\left(3.0 \pm 0.1 \mathrm{mg} \mathrm{L}^{-1}\right)$ and

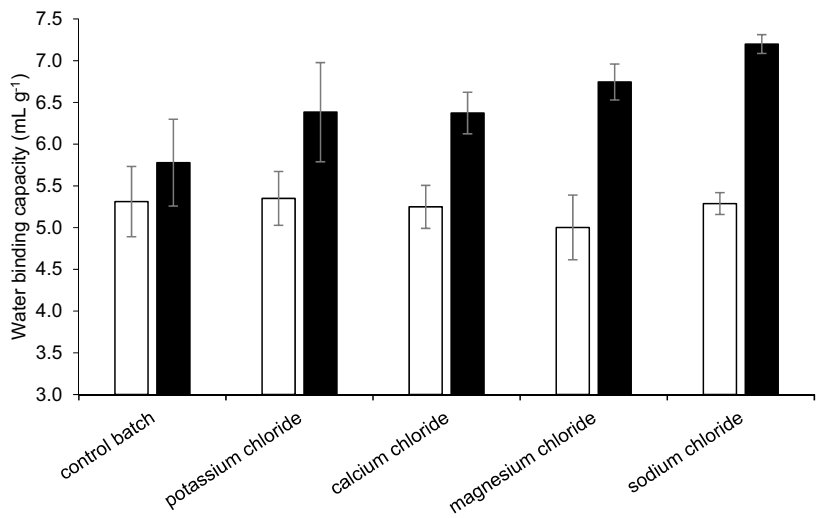

Fig. 3 Water binding capacity of mycelium of P. sapidus grown on apple pomace depending upon the addition of chlorides; unheated system (white), heated system (black); $(n=5)$. Vertical lines on top of the bars refer to the value of the standard error (SE)

soy protein concentrate $\left(4.0 \pm 0.1 \mathrm{mg} \mathrm{L}^{-1}\right)$. The $\mathrm{WBC}$ of the reference protein soy protein isolate $\left(6.7 \pm 0.2 \mathrm{mg} \mathrm{L}^{-1}\right)$ was comparable to that of $P$. sapidus.

The OBC of $P$. sapidus grown on apple pomace and of the plant proteins differed significantly. Soy and pea protein isolates showed OBC of $(0.9 \pm 0.1) \mathrm{mL} \mathrm{g}^{-1}$ and $(1.0 \pm 0.1) \mathrm{mL} \mathrm{g}^{-1}$, respectively, and soy protein concentrate showed $(1.0 \pm 0.1) \mathrm{mL} \mathrm{g}^{-1}$, while the OBC of P. sapi$d u s$ was $(6.7 \pm 0.1) \mathrm{mL} \mathrm{g}^{-1}$ (Stephan 2018). The high OBC seems to be mainly due to the presence of $\beta$-glucan in the fungal mycelium and the drying process applied. In a study of Petravić-Tominac et al. (2011), lyophilized $\beta$-glucan extracted from the ascomycetous yeast Saccharomyces cerevisiae revealed a 10 times higher $\mathrm{OBC}$ than air-dried or spray-dried $\beta$-glucan, whereas the WBC only varied marginally between the drying methods.

\section{Influence of various salts on WBC}

The influence of various chlorides on the WBC of $P$. sapi$d u s$ grown on apple pomace was tested (Fig. 3). For the
Fig. 2 Growth of Pleurotus sapidus in submerged culture on apple pomace. Vertical lines on top of the bars refer to the value of the standard error (SE)

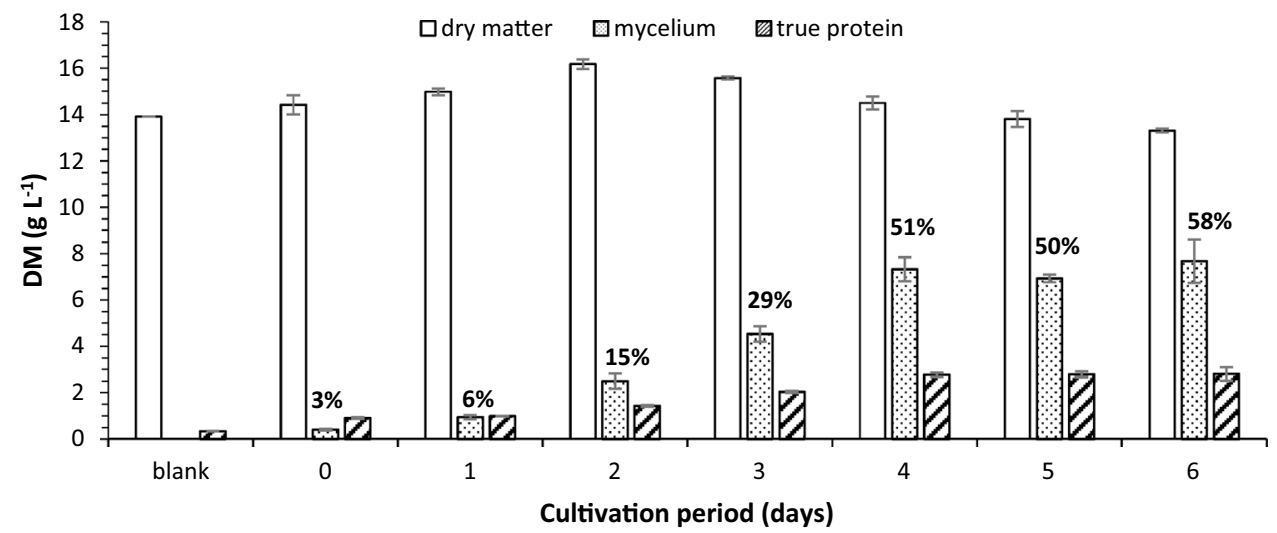

Springer 
unheated system, a minor decrease of the $\mathrm{WBC}$ was observed after addition of $\mathrm{MgCl}_{2}\left(5.00 \pm 0.39 \mathrm{~mL} \mathrm{~g}^{-1}\right)$ compared to the control batch which contained no additives $\left(5.31 \pm 0.42 \mathrm{~mL} \mathrm{~g}^{-1}\right)$. After heating at $80{ }^{\circ} \mathrm{C}$ for $1 \mathrm{~h}$, the WBC of all samples increased. A significant difference in comparison to the control $\left(5.78 \pm 0.52 \mathrm{~mL} \mathrm{~g}^{-1}\right)$ was detected for the use of $\mathrm{CaCl}_{2}\left(6.37 \pm 0.25 \mathrm{~mL} \mathrm{~g}^{-1}\right), \mathrm{MgCl}_{2}$ $\left(6.75 \pm 0.22 \mathrm{~mL} \mathrm{~g}^{-1}\right)$, and $\mathrm{NaCl}\left(7.20 \pm 0.11 \mathrm{~mL} \mathrm{~g}^{-1}\right)$. Similar increases in WBC have been reported for soy proteins (Nishinari et al. 2014), meat protein (Desmond 2006) and other plant protein systems (Ragab et al. 2004; Ahmed 2016).

\section{Conclusions}

Vegetative mycelia of mushrooms, produced by submerged cultivation on industrial side streams such as apple pomace showed beneficial nutritional properties. The substrate, apple pomace, can be valorized by fermentation with basidiomycetes and the resultant biomass appears to be suitable for use as an alternative protein source. The mycelia contain all essential amino acids and polyunsaturated fatty acids, especially linoleic acid (45\%). Vitamin $\mathrm{D}_{2}$ may easily be produced from the ergosterol present in the mycelium by exposure to UV-B light. In addition, ergosterol could be used as an indicator for fungal growth in cultures containing debris from by-products of the agro industry. The water binding capacity of $P$. sapidus grown on apple pomace was similar to that of the reference protein soy protein isolate, whereas the oil binding capacity was significantly higher than that of vegetable proteins.

Acknowledgements The authors thank the Bundesministerium für Wirtschaft und Energie for funding the ZIM-cooperation project KF3310001CS4. The study has partially been financed with funds of LOEWE-Landes-Offensive zur Entwicklung Wissenschaftlich-ökonomischer Exzellenz-AromaPlus (State Offensive for the Development of Scientific and Economic Excellence).

Open Access This article is licensed under a Creative Commons Attribution 4.0 International License, which permits use, sharing, adaptation, distribution and reproduction in any medium or format, as long as you give appropriate credit to the original author(s) and the source, provide a link to the Creative Commons licence, and indicate if changes were made. The images or other third party material in this article are included in the article's Creative Commons licence, unless indicated otherwise in a credit line to the material. If material is not included in the article's Creative Commons licence and your intended use is not permitted by statutory regulation or exceeds the permitted use, you will need to obtain permission directly from the copyright holder. To view a copy of this licence, visit http://creativecommons.org/licenses/by/4.0/.

\section{References}

Aghili AH, Toghyani M, Tabeidian SA (2019) Effect of incremental levels of apple pomace and multi enzyme on performance, immune response, gut development and blood biochemical parameters of broiler chickens. Int J Recycl Org Waste Agricult. https:// doi.org/10.1007/s40093-019-00305-8

Ahlborn J, Calzolari N, Spielmeyer A, Avci SS, Zimmer M, Rühl $M$ (2018) Enrichment of vitamin $\mathrm{D}_{2}$ in mycelium from submerged cultures of the agaric mushroom Pleurotus sapidus. J Food Sci Technol 55:3833-3839. https://doi.org/10.1007/s1319 7-018-3290-z

Ahmed SMO (2016) Isolation of the protein concentrate from the leaves of Moringa oleifera and study of its functional properties. Dissertation, Sudan University of Science and Technology

Alam N, Amin R, Khan A, Ara I, Shim MJ, Lee MW, Lee TS (2008) Nutritional analysis of cultivated mushrooms in BangladeshPleurotus ostreatus, Pleurotus sajor-caju, Pleurotus florida and Calocybe indica. Mycobiology 36:228-232. https://doi. org/10.4489/MYCO.2008.36.4.228

Alam N, Amin R, Khan A, Ara I, Shim MJ, Lee MW, Lee UY, Lee TS (2009) Comparative effects of oyster mushrooms on lipid profile, liver and kidney function in hypercholesterolemic rats. Mycobiology 37:37-42. https://doi.org/10.4489/ MYCO.2009.37.1.037

Andersen G, Soyka K (2011) Lebensmitteltabelle für die Praxis, vol 5 and 9,5th edn. Wissenschaftliche Verlagsgesellschaft, Stuttgart (Part B)

Bosse AK, Fraatz MA, Zorn H (2013) Formation of complex natural flavours by biotransformation of apple pomace with basidiomycetes. Food Chem 141:2952-2959. https://doi.org/10.1016/j. foodchem.2013.05.116Commission (Directive 98/64/EC of 3 September 1998 establishing Community methods of analysis for the determination of amino-acids, crude oils and fats, and olaquindox in feedingstuffs and amending Directive 71/393/ EEC. Official Journal of the European Communities, L257/14)

Crisan EV, Sands A (1978) Nutritional value. In: Chang ST, Hayes WA (eds) The biology and cultivation of edible mushrooms. Academic Press, London, pp 137-168

Desmond E (2006) Reducing salt: a challenge for the meat industry. Meat Sci 74:188-196. https://doi.org/10.1016/j.meats ci.2006.04.014

Dimou DM, Georgala A, Komaitis M, Aggelis G (2002) Mycelial fatty acid composition of Pleurotus spp. and its application in the intrageneric differentiation. Mycol Res 106:925-929. https://doi. org/10.1017/S0953756202006184

Food and Agriculture Organization of the United Nations (FAO) (2018) http://www.fao.org/faostat/en/\#data/QC. Accessed 14 Feb 2019

Givens DI, Barber WP (1987) Nutritive value of apple pomace for ruminants. Anim Feed Sci Tech 16:311-315. https://doi. org/10.1016/0377-8401(87)90020-4

Guo LQ, Lin JY, Lin JF (2007) Non-volatile components of several novel species of edible fungi in China. Food Chem 100:643-649. https://doi.org/10.1016/j.foodchem.2005.09.087

Hadar Y, Cohen-Azari E (1986) Chemical composition of the edible mushroom Pleurotus ostreatus produced by fermentation. Appl Environ Microb 51:1352-1354

Kammerer DR, Kammerer J, Valet R, Carle R (2014) Recovery of polyphenols from the by-products of plant food processing and application as valuable food ingredients. Food Res Int 65:2-12. https://doi.org/10.1016/j.foodres.2014.06.012

Kavishree S, Hemavathy J, Lokesh BR, Shashirekha MN, Rajarathnam S (2008) Fat and fatty acids of Indian edible mushrooms. Food Chem 106:597-602. https://doi.org/10.1016/j.foodc hem.2007.06.018 
Kim YD, Kim BK, Park HK (2005) Ergosterol content of basidiomycetes culture in rice. Int Rice Res Notes 30:43-44

Kjeldahl J (1883) Neue Methoden zur Bestimmung des Stickstoffs in organischen Körpern. Z Anal Chem 22:366-382. https://doi. org/10.1007/bf01338151

Klamer M, Bååth E (2004) Estimation of conversion factors for fungal biomass determination in compost using ergosterol and PLFA 18:2ఱ6,9. Soil Biol Biochem 36:57-65. https://doi.org/10.1016/j. soilbio.2003.08.019

Manzi P, Pizzoferrato L (2000) Beta-glucans in edible mushrooms. Food Chem 68:315-318. https://doi.org/10.1016/S0308 -8146(99)00197-1

Manzi P, Gambelli L, Marconi S, Vivanti V, Pizzoferrato L (1999) Nutrients in edible mushrooms: an inter-species comparative study. Food Chem 65:477-482. https://doi.org/10.1016/S0308 -8146(98)00212-X

Martin F, Delaruelle C, Hilbert JL (1990) An improved ergosterol assay to estimate fungal biomass in ectomycorrhizas. Mycol Res 94:1059-1064. https://doi.org/10.1016/S0953-7562(09)81333-6

Matissek R, Steiner G, Fischer M (2010) Aminosäuren, peptide, proteine, nucleinsäuren. In: Matissek R, Steiner G, Fischer M (eds) Lebensmittelanalytik, 5th edn. Springer, Berlin, pp 271-279

Mattila P, Salo-Väänänen P, Könkö K, Aro H, Jalava T (2002) Basic composition and amino acid contents of mushrooms cultivated in Finland. J Agr Food Chem 50:6419-6422. https://doi.org/10.1021/ jf020608m

Miller SA, Dwyer JT (2001) Evaluating the safety and nutritional value of myco-protein. Food Technol 55:42-47

Nishinari K, Fang Y, Guo S, Phillips GO (2014) Soy proteins: a review on composition, aggregation and emulsification. Food Hydrocoll 39:301-318. https://doi.org/10.1016/j.foodhyd.2014.01.013

Ooijkaas LP, Tramper J, Buitelaar RM (1998) Biomass estimation of Coniothyrium Minitans in solid-state fermentation. Enzyme Microb Technol 22:480-486. https://doi.org/10.1016/S0141 -0229(97)00246-9

Petravić-Tominac V, Zechner-Krpan V, Berković K, Galović P, Herceg Z, Srečec S, Špoljarić I (2011) Rheological properties, water-holding and oil-binding capacities of particulate $\beta$-glucans isolated from spent brewer's yeast by three different procedures. Food Technol Biotech 49:56-64

Porep JU, Walter R, Kortekamp A, Carle R (2014) Ergosterol as an objective indicator for grape rot and fungal biomass in grapes. Food Control 37:77-84. https://doi.org/10.1016/j.foodc ont.2013.09.012

Ragab DM, Babiker EE, Eltinay AH (2004) Fractionation, solubility and functional properties of cowpea (Vigna unguiculata) proteins as affected by $\mathrm{pH}$ and/or salt concentration. Food Chem 84:207212. https://doi.org/10.1016/S0308-8146(03)00203-6

Ravn-Haren G, Krath BN, Markowski J, Poulsen M, Hansen M, Kotodziejczyk K, Kosmala M, Dragsted LO (2018) Apple pomace improves gut health in fisher rats independent of seed content. Food Funct 9:2931-2941. https://doi.org/10.1039/c7fo01932g

Regulation (EU) No 1169/2011 of the European Parliament and of the Council of 25 October 2011 on the provision of food information to consumers, amending Regulations (EC) No 1924/2006 and (EC) No 1925/2006 of the European Parliament and of the Council, and repealing Commission Directive 87/250/EEC, Council Directive 90/496/EEC, Commission Directive 1999/10/ EC, Directive 2000/13/EC of the European Parliament and of the Council, Commission Directives 2002/67/EC and 2008/5/EC and Commission Regulation (EC) No 608/2004

Roberts JS, Teichert A, McHugh TH (2008) Vitamin $\mathrm{D}_{2}$ formation from post-harvest UV-B treatment of mushrooms (Agaricus bisporus) and retention during storage. J Agric Food Chem 56:45414544. https://doi.org/10.1021/jf0732511

Rodger G (2001) Mycoprotein-a meat alternative new to the US. Food Technol 55:36-41
Rop O, Mlcek J, Jurikova T (2009) Beta-glucans in higher fungi and their health effects. Nutr Rev 67:624-631. https://doi.org/10.111 1/j.1753-4887.2009.00230.x

Schneider I, Kressel G, Meyer A, Krings U, Berger RG, Hahn A (2011) Lipid lowering effects of oyster mushroom (Pleurotus ostreatus) in humans. J Funct Food 3:17-24. https://doi.org/10.1016/j. jff.2010.11.004

Seitz LM, Mohr HE, Burroughs R, Sauer DB (1977) Ergosterol as an indicator of fungal invasion in grains. Cereal Chem 54:1207-1217

Seitz LM, Sauer DB, Burroughs R, Mohr HE, Hubbard JD (1979) Ergosterol as a measure of fungal growth. Phytopathology 69:1202-1203

Singh P, Kumar R, Sabapathy SN, Bawa AS (2008) Functional and edible uses of soy protein products. Compr Rev Food Sci F 7:14-28. https://doi.org/10.1111/j.1541-4337.2007.00025.x

Smith RL, Gilkerson E (1979) Quantitation of glycosaminoglycan hexosamine using 3-methyl-2-benzothiazolone hydrazone hydrochloride. Anal Biochem 98:478-480. https://doi. org/10.1016/0003-2697(79)90170-2

Stephan A (2018) Produktentwicklung von innovativen Lebensmitteln auf Basis einer alternativen Proteinquelle aus Basidiomyceten. Dissertation, Justus-Liebig-University Giessen

Stephan A, Ahlborn J, Zajul M, Zorn H (2018) Edible mushroom mycelia of Pleurotus sapidus as novel protein sources in a vegan boiled sausage analog system: functionality and sensory tests in comparison to commercial proteins and meat sausages. Eur Food Res Technol 244:913-924. https://doi.org/10.1007/s0021 7-017-3012-1

Steudler S, Bley T (2015) Biomass estimation during macro-scale solid-state fermentation of basidiomycetes using established and novel approaches. Bioproc Biosyst Eng 38:1313-1323. https://doi. org/10.1007/s00449-015-1372-0

Trapp T, Zajul M, Ahlborn J, Stephan A, Zorn H, Fraatz MA (2018) Submerged cultivation of Pleurotus sapidus with molasses: aroma dilution analyses by means of solid phase microextraction and stir bar sorptive extraction. J Agric Food Chem 66:2393-2402. https ://doi.org/10.1021/acs.jafc.6b05292

Vendruscolo F, Albuquerque PM, Streit F, Esposito E, Ninow JL (2008) Apple pomace: a versatile substrate for biotechnological applications. Crit Rev Biotechnol 28:1-12. https://doi.org/10.1080/07388 550801913840

Villas-Bôas SG, Esposito E, Mendoça MM (2003) Bioconversion of apple pomace into a nutritionally enriched substrate by Candida utilis and Pleurotus ostreatus. World J Micro Biot 19:461-467. https://doi.org/10.1023/A:1025105506004

Wittig M, Krings U, Berger RG (2013) Single-run analysis of vitamin $\mathrm{D}$ photoproducts in oyster mushroom (Pleurotus ostreatus) after UV-B treatment. J Food Compos Anal 31:266-274. https://doi. org/10.1016/j.jfca.2013.05.017

Worrall JJ, Yang CS (1992) Shiitake and oyster mushroom production on apple pomace and sawdust. Hort Sci 27:1131-1133

Yilmaz N, Solmaz M, Türkekul I, Elmastaş M (2006) Fatty acid composition in some wild edible mushrooms growing in the middle Black Sea region of Turkey. Food Chem 99:168-174. https://doi. org/10.1016/j.foodchem.2005.08.017

Zelles L, Hund K, Stepper K (1987) Methoden zur relativen Quantifizierung der pilzlichen Biomasse im Boden. Zeitschrift für Pflanzenernährung und Bodenkunde 150:249-252. https://doi. org/10.1002/jpln.19871500410

Publisher's Note Springer Nature remains neutral with regard to jurisdictional claims in published maps and institutional affiliations. 